\title{
Performance indicators for road bridges - overview of findings and future progress
}

\author{
Alfred Strauss ${ }^{1}$, Ana MandićIvanković ${ }^{2}$, Jose Campos e Matos ${ }^{3}$, Joan Ramon Casas ${ }^{4}$ \\ DOI: $\underline{\text { https://doi.org/10.5592/CO/BSHM2017.3.1 }}$ \\ ${ }^{l}$ Department of Civil Engineering and Natural Hazards, Institute of Structural Engineering, University of \\ Natural Resources and Life Sciences, 1190 Vienna, Austria, \\ ${ }^{2}$ Department of Structural Engineering, Faculty of Civil Engineering, University of Zagreb, Kačićeva 26, \\ Zagreb 10000, Croatia, \\ ${ }^{3}$ Department of Civil Engineering, Minho University, Guimarães, Portugal, \\ ${ }^{4} U P C-B a r c e l o n a$ Tech, Barcelona, Spain
}

\author{
E-mails: ${ }^{1} a l f r e d . s t r a u s s @ b o k u . a c . a t ;{ }^{2}$ mandicka@grad.hr; ${ }^{3}$ chair@tu1406.eu; \\ ${ }^{4}$ joan.ramon.casas@upc.edu.
}

\begin{abstract}
One of the main objectives of COST Action TU 1406 is to build a performance indicator database, in order to develop technical recommendations which will specify the performance goals, aiming to provide a methodology with detailed step-by-step explanations for establishment of QC plans for different bridge types. This paper presents the main findings of Working Group 1: Performance Indicators (PI), based on analysis of documents related to bridge maintenance, assessment and management from different European countries through surveying, clustering, homogenization and categorization. In addition, further steps in order to correlate with the objectives of the Working Group 2, whose work is dedicated to revealing Performance Goals (PG), and the Working Group 3, dedicated to the establishment of Quality Control (QC) plans, if is foreseen.
\end{abstract}

Keywords: performance indicators, operators' database, research based database, performance levels \& aspects, performance goals, performance thresholds, weighting factors

\section{Introduction}

The main objective of the COST Action TU1406 is to develop a guideline for the establishment of QC plans in roadway bridges, by integrating the most recent knowledge on performance assessment procedures with the adoption of specific goals (Matos, 2016, Matos et al., 2016). This guideline will focus on bridge maintenance and lifecycle performance at two levels: (i) performance indicators and (ii) performance goals. The possibility to incorporate new indicators related to sustainable performance will also be considered. By developing new approaches to quantify and assess bridge performance, as well as quality specifications to assure expected performance levels, bridge management strategies will be significantly improved, enhancing asset management of ageing structures in Europe.

In order to reach this main general aim through more specific objectives and deliverables, the work was structured in several Working Groups. This paper presents the main findings of Working Group 1: Performance Indicators based on analysis of the operators' and research based database. Operators' database was created by surveying documents related to bridge maintenance, assessment and management from different European countries and research based database through surveying scientific documents by answering to several questions. In addition, further steps in order to correlate with the objectives of the Working Group 2 whose work is dedicated to revealing Performance Goals and the Working Group 3 dedicated to the establishment of Quality Control plans is foreseen.

\section{Surveying and main findings}

Through the WG1 activities, the development of a performance indicators database has been defined as an essential component of the COST Action TU1406. The core of the survey process was structured as a user interface in Excel by storing information in four main groups (Strauss et al., TU 1406 WG1 Report, 2016): Performance level, Damage, Performance indicator/index and Performance assessment. Besides this data, there was an opportunity to add additional references and specific information about a group element (e.g. evaluation 
process, formula, figure, etc.). The background for this structure comes from screening of the Austrian national document (Bundesministerium für Verkehr, Innovation und Technologie, 2011) and two documents from United Kingdom (County Surveyors Society CSS, 2004). In order to support on the interface in the screening process, a Glossary of key terms is required to store the information and terminology related to Performance Indicators, Performance Goals, Performance Thresholds and Performance Method. It has been prepared on the basis of the information from German and Austrian documents (BASt, 2015, Bundesministerium für Verkher, Innovation und Technologie, 2011).

The selected screening methodology is based on a deep analysis of the existing bridge inspection and evaluation policies in European countries and the main performance indicators used with the objective to define a common group of quality specifications and control plans that can be assumed by all these countries in the next future. This, with the aim to manage the existing roadway infrastructure from an European and not only a countryspecific perspective. From the first review of the screening background documents, and the database for performance indicators, main findings are as follows.

The most widely used performance indicator is the condition index, condition rating, deterioration index,..., whatever it is called by different countries and operators, mainly obtained from visual inspection. All surveyed countries have a performance indicator related to this subject. Similar rating system as shown in table 1 is used for many of the countries.

Table 1 Exemplary rating system used in Austria and Croatia

\begin{tabular}{cl}
\hline Rating Index & Description \\
\hline 1 & $\begin{array}{l}\text { No or very slight damage, normal age-related wear and tear, aesthetic damage. } \\
\text { No decrease in load carrying capacity, serviceability and predicted life time. } \\
\text { No measures required. }\end{array}$ \\
\hline 2 & $\begin{array}{l}\text { Slight damage, production defects with no signs of further deterioration. } \\
\text { No decrease in load carrying capacity and serviceability. } \\
\text { If no suitable measures are taken, the predicted life time will decrease. Repair measures are required in } \\
\text { the course of the next maintenance action. }\end{array}$ \\
& $\begin{array}{l}\text { Moderate to severe damage with no decrease in load carrying capacity and serviceability. } \\
\text { Signs of deterioration regarding load carrying capacity and serviceability. } \\
\text { Medium-term maintenance and repair actions are necessary in order to preserve the serviceability and } \\
\text { expected life time of the structure. }\end{array}$ \\
\hline & $\begin{array}{l}\text { Severe damage, with no decrease in load carrying capacity. } \\
\text { Deterioration in terms of serviceability and expected life time can already be observed. } \\
\text { Maintenance measures are to be instigated as soon as possible in order to safeguard the serviceability and } \\
\text { the expected life time. Such measures may be substituted by additional special inspections within a } \\
\text { defined time frame. }\end{array}$ \\
\hline 5 & $\begin{array}{l}\text { Extreme damage with impact on the load carrying capacity of the structure. } \\
\text { Repair and maintenance measures must be performed immediately. }\end{array}$ \\
\hline
\end{tabular}

In many countries, this is the only performance indicator used in practice by bridge owners and operators. However, some countries like Denmark and The Netherlands have started to use other relevant indicators in the assessments made by bridge owners, and not only at a research level. For instance in Denmark, the concepts of remaining service life, safety index-reliability, vulnerability and robustness appear. In The Netherlands the performance is measured in terms of reliability, availability, maintainability and safety/risk (RAMS) among others. The concept of risk is respectively used to define several new indicators: a social indicator, environmental indicator, economic indicator and political indicator (requirements for public image).

Inspection and monitoring strategies for existing bridges, aim at the evaluation and assessment of structural safety and reliability (load carrying capacity, serviceability), with the ultimate objective of determining the traffic safety. Monitoring and evaluation measures are recommended with the aim of improving the understanding and the general assessment of the condition of the structure or also as a special inspection which enables the identification and localization of damage in time. The ultimate objective is to safeguard the performance over the whole life-span. The basis of any kind of monitoring is always a detailed inspection. Such inspections may be subdivided in four time-related categories (e.g. Austria):

- Visual inspections, e.g. yearly basis.

- Simple checks, for instance 3 years after every main inspection.

- In-depth examinations or main inspections, for instance, every 6 years.

- Special inspections, following exceptional occurrences or incidents. 

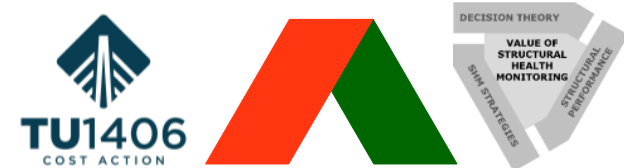

The Value of Structural Health Monitoring for the reliable Bridge Management

Zagreb 2-3 March 2017

In case of defects or deficiencies, special inspections and further tests or examinations need to be conducted with the aim of assessing whether or not these defects have any impact on the structure serviceability. On this basis, it shall be decided whether the deficiencies and/or damages are to be repaired in the course of the next maintenance action. In general, in-depth examinations should be performed at intervals of no longer than 6 years.

\section{Clustering and homogenization of PI database}

After collecting the input from different countries, based on surveying of inspection and evaluation documents related to bridge maintenance, assessment and management, it was concluded that results are partly heterogeneous with a number of overlaps. This mainly results from free interpretation leeway and different know-how of experts in visual inspections, performance evaluation, performance assessment and decision making. In some way, there was also some misunderstanding about what are performance indicators and how are they obtained (Strauss et al., TU 1406 WG1 Report, 2016).

\begin{tabular}{|c|c|c|c|c|c|c|c|c|c|c|}
\hline defects & $\begin{array}{l}\text { related to } \\
\text { material } \\
\text { properties }\end{array}$ & $\begin{array}{l}\text { related to } \\
\text { equipment \& } \\
\text { protection }\end{array}$ & $\begin{array}{l}\text { geometry } \\
\text { changes }\end{array}$ & $\begin{array}{l}\text { related to } \\
\text { bearing } \\
\text { capacity, } \\
\text { structural } \\
\text { integrity and } \\
\text { joints }\end{array}$ & $\begin{array}{l}\text { related to } \\
\text { original } \\
\text { construction } \\
\text { and design }\end{array}$ & $\begin{array}{l}\text { related to } \\
\text { dynamic } \\
\text { behaviour }\end{array}$ & $\begin{array}{l}\text { environment } \\
\text { al based } \\
\text { (common } \\
\text { appearance) }\end{array}$ & rating & $\begin{array}{l}\text { cost and } \\
\text { importance }\end{array}$ & loads \\
\hline $\begin{array}{l}\text { abrasion } \\
\text { absence/ } \\
\text { missing }\end{array}$ & $\begin{array}{l}\text { acids attacks } \\
\text { aggregate } \\
\text { segregation }\end{array}$ & $\begin{array}{l}\text { absence } \\
\text { (missing) of } \\
\text { equipment } \\
\text { component } \\
\text { approach slab } \\
\text { settlement }\end{array}$ & $\begin{array}{l}\text { buckling } \\
\text { cross incline } \\
\text { of road }\end{array}$ & $\begin{array}{l}\text { absent } \\
\text { (missing) } \\
\text { structural } \\
\text { component } \\
\text { accumulated } \\
\text { dirt and } \\
\text { deposits in } \\
\text { joints }\end{array}$ & $\begin{array}{l}\text { accessibility } \\
\text { to damage }\end{array}$ & $\begin{array}{l}\text { atypical } \\
\text { vibrations }\end{array}$ & $\begin{array}{l}\text { biological } \\
\text { growth }\end{array}$ & $\begin{array}{l}\text { advanced } \\
\text { deterioration } \\
\text { process }\end{array}$ & $\begin{array}{l}\text { bridge } \\
\text { importance } \\
\text { (size) } \\
\text { element } \\
\text { functionality } \\
\text { level }\end{array}$ & $\begin{array}{l}\text { gross weight } \\
\text { of a vehicle } \\
\text { permanent } \\
\text { loading }\end{array}$ \\
\hline $\begin{array}{l}\text { aggradation } \\
\text { (alluviation) }\end{array}$ & $\begin{array}{l}\text { aging of } \\
\text { material } \\
\text { alkali } \\
\text { aggregate } \\
\text { reaction } \\
\text { (alkali-silica } \\
\text { reaction) }\end{array}$ & $\begin{array}{l}\text { asphalt } \\
\text { pavement } \\
\text { cracking } \\
\text { asphalt } \\
\text { pavement } \\
\text { wearing and } \\
\text { tearing } \\
\text { (rutting, } \\
\text { ravelling) }\end{array}$ & deformation & $\begin{array}{l}\text { anchorage } \\
\text { blocks } \\
\text { deficiency }\end{array}$ & $\begin{array}{l}\text { carrying } \\
\text { capacity } \\
\text { factor }\end{array}$ & frequency & $\begin{array}{l}\text { environmenta } \\
\text { lexposure }\end{array}$ & $\begin{array}{l}\text { condition of a } \\
\text { bridge }\end{array}$ & $\begin{array}{l}\text { importance of } \\
\text { bridge } \\
\text { element }\end{array}$ & traffic loading \\
\hline blocking & $\begin{array}{l}\text { alkali } \\
\text { aluminium } \\
\text { reaction }\end{array}$ & $\begin{array}{l}\text { asphalt } \\
\text { pavement } \\
\text { wheel } \\
\text { tracking and } \\
\text { wrinkling and } \\
\text { undulation }\end{array}$ & $\begin{array}{l}\text { differential } \\
\text { movement }\end{array}$ & $\begin{array}{l}\text { arch ring } \\
\text { separation }\end{array}$ & $\begin{array}{l}\text { cracks due to } \\
\text { curing and } \\
\text { forming }\end{array}$ & $\begin{array}{l}\text { real dynamic } \\
\text { behaviour }\end{array}$ & humidity & damage & $\begin{array}{l}\text { sum of costs } \\
\text { for repair of } \\
\text { individual } \\
\text { damages }\end{array}$ & \\
\hline bulging & $\begin{array}{l}\text { bad concrete } \\
\text { compaction }\end{array}$ & $\begin{array}{l}\text { blistering } \\
\text { paint }\end{array}$ & displacement & $\begin{array}{l}\text { barrel } \\
\text { damage to } \\
\text { stone arches }\end{array}$ & design codes & $\begin{array}{l}\text { relative } \\
\text { vibrations } \\
\text { between } \\
\text { elements }\end{array}$ & moisture & $\begin{array}{l}\text { damage } \\
\text { assessment }\end{array}$ & $\begin{array}{l}\text { traffic } \\
\text { restrictions }\end{array}$ & \\
\hline cavitation & $\begin{array}{l}\text { bedding } \\
\text { mortar failure }\end{array}$ & $\begin{array}{l}\text { cladding } \\
\text { damages }\end{array}$ & distortion & $\begin{array}{l}\text { bearing } \\
\text { defects }\end{array}$ & design load & sound & soot & $\begin{array}{l}\text { damage } \\
\text { degree }\end{array}$ & traffic volume & \\
\hline
\end{tabular}

Fig. 1. Cut-out from clustering table of PI related terms for homogenization of the applied database

Therefore, a critical overview of contributions from different countries, with respect to the content and definitions, was necessary. In order to do that, clustering of performance indicators into several groups is suggested. Clustering was guided with the thought that it should allow to more easily identify methods and procedures for revealing and quantifying of performance indicators as well as to define levels of their contribution to a certain structural performance goal. The clustering procedure allowed to reduce the list of terms related to performance indicators in half, from more than 700 hundred of terms into 385. Cut-out from the list of clustered terms is shown at the Figure 1.

Further, the clustering served for homogenisation of the complete European Database, in order to harmonize the Performance Indicators from an European perspective. Example of homogenisation within the Croatian database is shown at the Figure 2. For each available cluster of performance indicators, one example for converting terms 
from original database into a homogenised one is given. The nominated persons were asked again to verify their performance and damage specific inputs by comparing it with the homogenized terms which are available by a drop-down list in the extended homogenization field. This procedure with the extended homogenized fields by retaining the original information of the databases allows an effective comparison of the performance quantities between countries. Upon homogenisation from all countries the number of indicators was significantly reduced.

\begin{tabular}{|c|c|c|c|c|c|c|c|c|c|c|}
\hline \multicolumn{4}{|c|}{ A) Performance Level } & \multicolumn{2}{|c|}{ B) Damage } & \multicolumn{2}{|c|}{$\begin{array}{l}\text { C) Performance } \\
\text { Indicator/Index }\end{array}$} & \multicolumn{2}{|c|}{$\begin{array}{l}\text { D) Performance } \\
\text { Assessment }\end{array}$} & \\
\hline level & system & $\begin{array}{c}\text { compo- } \\
\text { nent }\end{array}$ & material & type & $\begin{array}{c}\text { charact- } \\
\text { eristic }\end{array}$ & indicator & detection & $\begin{array}{l}\text { thresh- } \\
\text { old }\end{array}$ & goal & \\
\hline $\begin{array}{l}\text { Sub } \\
\text { System }\end{array}$ & \begin{tabular}{|l|} 
All \\
bridge \\
types
\end{tabular} & $\begin{array}{l}\text { Super } \\
\text { Structure }\end{array}$ & Concrete & $\begin{array}{l}\text { Damage } \\
\text { State }\end{array}$ & Cracks & $\begin{array}{l}\text { Damage } \\
\text { degree }\end{array}$ & $\begin{array}{l}\text { Direct } \\
\text { Measure- } \\
\text { ment }\end{array}$ & $\begin{array}{l}\text { crack } \\
\text { width } \\
(\mathrm{mm})\end{array}$ & $\begin{array}{l}\text { Damage } \\
\text { Assess- } \\
\text { ment }\end{array}$ & $\begin{array}{l}\text { DEFECTS } \\
\text { Crack width }\end{array}$ \\
\hline $\begin{array}{l}\text { Sub } \\
\text { System }\end{array}$ & $\begin{array}{l}\text { All } \\
\text { bridge } \\
\text { types }\end{array}$ & $\begin{array}{l}\text { Super } \\
\text { Structure }\end{array}$ & Concrete & $\begin{array}{l}\text { Damage } \\
\text { State }\end{array}$ & $\begin{array}{l}\text { Honey- } \\
\text { combing }\end{array}$ & $\begin{array}{l}\text { Damage } \\
\text { degree }\end{array}$ & $\begin{array}{l}\text { Direct } \\
\text { Measure- } \\
\text { ment }\end{array}$ & $\begin{array}{l}\text { affected } \\
\text { area } \\
(\mathrm{m} 2)\end{array}$ & $\begin{array}{l}\text { Damage } \\
\text { Assess- } \\
\text { ment }\end{array}$ & $\left\{\begin{array}{c}\text { MATERIAL PROPERTIES } \\
\text { bad concrete } \\
\text { compaction }\end{array}\right.$ \\
\hline 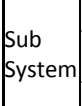 & $\begin{array}{l}\text { All } \\
\text { bridge } \\
\text { types }\end{array}$ & $\begin{array}{l}\text { Super } \\
\text { Structure }\end{array}$ & & $\begin{array}{l}\text { Damage } \\
\text { State }\end{array}$ & $\begin{array}{l}\text { Freeze- } \\
\text { thaw }\end{array}$ & $\begin{array}{l}\text { Damage } \\
\text { degree }\end{array}$ & $\begin{array}{l}\text { Direct } \\
\text { Measure- } \\
\text { ment }\end{array}$ & $\begin{array}{l}\text { affected } \\
\text { area } \\
(\mathrm{m} 2)\end{array}$ & $\begin{array}{l}\text { Damage } \\
\text { Assess- } \\
\text { ment }\end{array}$ & $\begin{array}{c}\text { ENVIRONMENTAL } \\
\text { BASED } \\
\text { freeze-thaw }\end{array}$ \\
\hline $\begin{array}{l}\text { Sub } \\
\text { System }\end{array}$ & \begin{tabular}{|l|} 
All \\
bridge \\
types
\end{tabular} & $\begin{array}{l}\text { Super } \\
\text { Structure }\end{array}$ & Brick & $\begin{array}{l}\text { Damage } \\
\text { State }\end{array}$ & $\begin{array}{l}\text { Disinte- } \\
\text { gration } \\
\text { of mortar }\end{array}$ & Damage & $\begin{array}{l}\text { Visual } \\
\text { Inspection }\end{array}$ & & $\begin{array}{l}\text { Damage } \\
\text { Assess- } \\
\text { ment }\end{array}$ & $\left\{\begin{array}{c}\text { STRUCTURAL INTEGRITY } \\
\text { \& JOINTS } \\
\text { disintegration of mortar }\end{array}\right.$ \\
\hline $\begin{array}{l}\text { Sub } \\
\text { System }\end{array}$ & $\begin{array}{l}\text { All } \\
\text { bridge } \\
\text { types }\end{array}$ & Railings & Steel & $\begin{array}{l}\text { Damage } \\
\text { State }\end{array}$ & $\begin{array}{l}\text { Missing } \\
\text { parts }\end{array}$ & $\begin{array}{l}\text { Damage } \\
\text { degree }\end{array}$ & \begin{tabular}{|l} 
Visual \\
Inspection
\end{tabular} & & $\begin{array}{l}\text { Damage } \\
\text { Assess- } \\
\text { ment }\end{array}$ & $\begin{array}{c}\text { EQUIPMENT AND } \\
\text { PROTECTION } \\
\text { absence of equipment } \\
\text { component }\end{array}$ \\
\hline System & \begin{tabular}{|l|} 
All \\
bridge \\
types
\end{tabular} & & & $\begin{array}{l}\text { Damage } \\
\text { State }\end{array}$ & Buckling & $\begin{array}{l}\text { Damage } \\
\text { degree }\end{array}$ & $\begin{array}{l}\text { Visual } \\
\text { Inspection }\end{array}$ & & $\begin{array}{l}\text { Damage } \\
\text { Assess- } \\
\text { ment }\end{array}$ & $\begin{array}{l}\text { GEOMETRY CHANGES } \\
\text { Buckling }\end{array}$ \\
\hline System & \begin{tabular}{|l} 
All \\
bridge \\
types
\end{tabular} & & Concrete & $\begin{array}{l}\text { Damage } \\
\text { State }\end{array}$ & $\begin{array}{l}\text { Execut- } \\
\text { ion } \\
\text { defects }\end{array}$ & $\begin{array}{l}\text { Damage } \\
\text { degree }\end{array}$ & \begin{tabular}{|l} 
Direct \\
Measure- \\
ment
\end{tabular} & $\begin{array}{l}\text { affected } \\
\text { area } \\
(\mathrm{m} 2)\end{array}$ & $\begin{array}{l}\text { Damage } \\
\text { Assess- } \\
\text { ment }\end{array}$ & $\left\{\begin{array}{c}\text { ORIGINAL CONSTRUC- } \\
\text { TION \& DESIGN } \\
\text { execution/construction } \\
\text { defects }\end{array}\right.$ \\
\hline $\begin{array}{l}\text { Ele- } \\
\text { ment }\end{array}$ & & & & $\begin{array}{l}\text { Damag- } \\
\text { ing } \\
\text { Process }\end{array}$ & $\begin{array}{l}\text { low } \\
\text { damage } \\
\text { degree } \\
\text { (first } \\
\text { phase) }\end{array}$ & $\begin{array}{l}\text { Damage } \\
\text { degree }\end{array}$ & $\begin{array}{l}\text { Visual } \\
\text { Inspection }\end{array}$ & $\begin{array}{l}\text { Upper } \\
\text { limit } \\
+ \\
\text { Duration } \\
\text { of } \\
\text { damage } \\
\text { phase }\end{array}$ & $\begin{array}{l}\text { Damage } \\
\text { Assess- } \\
\text { ment }\end{array}$ & $\begin{array}{c}\text { RATING } \\
\text { damage degree } \\
\text { +damage evolution }\end{array}$ \\
\hline $\begin{array}{l}\text { Ele- } \\
\text { ment }\end{array}$ & & & & & & $\begin{array}{l}\text { Impor- } \\
\text { tance of } \\
\text { bridge } \\
\text { element }\end{array}$ & & $\begin{array}{l}\text { Quanti- } \\
\text { tative } \\
\text { scale o } \\
\text { values }\end{array}$ & $\begin{array}{l}\text { Element } \\
\text { impor- } \\
\text { tance } \\
\text { assess- } \\
\text { ment }\end{array}$ & $\left\{\begin{array}{c}\text { COST \& IMPORTANCE } \\
\text { importance of bridge } \\
\text { element }\end{array}\right.$ \\
\hline
\end{tabular}

Fig. 2. Example of homogenization of terms within the Croatian database

\section{From Performance Indicators to Key Performance Indicators}

It was agreed, among the TU 1406 community, that Performance Indicator is a measurable and quantifiable parameter related to the bridge performance that can be compared with a target measure of a performance goal or can be used for ranking purposes among a bridge population in the framework of a Quality Control Plan or lifecycle management (which includes decisions and actions involving economic resources).To evaluate certain performance indicator, performance thresholds or criteria must be set. A threshold value constitutes a boundary for purposes such as: a) monitoring (e.g. an effect is observed or not), b) assessing (e.g. an effect is low or high), and c) decision-making (e.g. an effect is critical or not). A criterion is a characteristic that is relevant for the choice between processes e.g. such as maintenance actions or others. Although the interaction of different performance indicators is inevitable, their categorization into technical, sustainable and socio-economic indicators through component, system and network level is proposed in order to more easily identify level of their influence to a certain key performance indicator related to performance goal.

In order to move on with the reduction of the list of Performance Indicators, an Expert Group was asked to specify PIs (YES/NO) according to the following points: Measurable?; Quantifiable?; Target value available?; Valid for ranking?; Allow decision with economic implications?. At the end, approximately 100 extricated PIs are further related with one or more Key Performance Indicators (KPI): Reliability (R), Availability (A), 

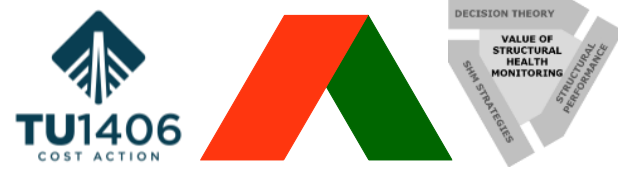

The Value of Structural Health Monitoring for the reliable Bridge Management

Maintainability (M), Safety (S), Security (Se), Environment (E), Costs (C), Health (H), Politics (P), Rating/Inspection (I). Further the process required the categorization of Performance Indicators in relation to Performance Goals (PG) and Performance Thresholds (PT) at different levels: component (CL), system (SL), network (NL); taking into account different aspects: technical (Tech), sustainability (Sust) and socio-economic (SoEc). Each expert's feedback was systemized as shown in the cut out example at the Figure 3.

\begin{tabular}{|c|c|c|c|c|c|c|}
\hline \multicolumn{7}{|c|}{ Safety, Reliability, Security } \\
\hline \multirow[b]{2}{*}{ PI } & Level & Performance indicator PI if & $\begin{array}{c}\text { PI belongs to the Key } \\
\text { Peformance }\end{array}$ & Assessment & & \\
\hline & $\begin{array}{l}\text { Component Level (CL) } \\
\text { System Level (SL) } \\
\text { Network Level (NL) }\end{array}$ & $\begin{array}{c}\text { Measurable? } \\
\text { \{Quantifiable? } \\
\text { Target value available? } \\
\text { Valid for ranking purposes? } \\
\text { Allow decision with economic } \\
\text { implications?\} (YES/No) } \\
\\
\text { Technical (Tech), Socio } \\
\text { Economical (SoEc), } \\
\text { Sustainable (Sust) }\end{array}$ & $\begin{array}{c}\text { Reliability (R), } \\
\text { Availability (A), } \\
\text { Maintainability (M), } \\
\text { Safety (S), } \\
\text { Security (Se), } \\
\text { Environment (E), } \\
\text { Costs (C), Health (H), } \\
\text { Politics (P), } \\
\text { Rating/Inspection (I) }\end{array}$ & $\begin{array}{c}\text { Threshold }(T=\ldots . .) \\
\text { Goal }(G=\ldots .) \\
\text { Rating }(R=\ldots .)\end{array}$ & rating (1-5) & weighting \\
\hline $\begin{array}{l}\text { concrete cover } \\
\text { (insufficient) }\end{array}$ & $\mathrm{CL}$ & Yes, Tech, Sust & $R, A,(C, I)$ & $\begin{array}{l}\mathrm{T}=\text { thickness }(\mathrm{mm}), \mathrm{G}=\text { assessment of } \\
\text { damage and affected area }(\mathrm{m} 2), \\
\mathrm{R}=\text { important for durability }\end{array}$ & 2 & 0,8 \\
\hline $\begin{array}{l}\text { origin (e.g. due to } \\
\text { loading, due to } \\
\text { settlement, due to } \\
\text { crumbling of } \\
\text { concrete,... }\end{array}$ & $\mathrm{CL}, \mathrm{SL}$ & & $R, A, S,(C, I)$ & \begin{tabular}{|l|}
$\mathrm{T}=$ width $(\mathrm{mm}), \mathrm{G}=$ understand origin through \\
the correlation of the observed thickness \\
$(\mathrm{mm})$, length $(\mathrm{cm})$, location/orientation and \\
spacing/pattern, R=key PI to access reliability
\end{tabular} & 3 & 0,5 \\
\hline fatigue cracking & $\mathrm{CL}, \mathrm{SL}$ & Yes, Tech & $R, A, S,(C, I)$ & $\begin{array}{l}\mathrm{T}=\text { number of cracks and affected } \\
\text { components; } \mathrm{G}=\text { local or generalized } \\
\text { situation and importance of affected } \\
\text { components; R= Key for reliability. }\end{array}$ & 5 & 0,3 \\
\hline settlement & SL & Yes, Tech & $R, A, S,(C, I)$ & $\begin{array}{l}\mathrm{T}=\text { dimension }(\mathrm{mm}) \text { and orientation }(\mathrm{o}), \mathrm{G}= \\
\text { Affected components, stable/evolving, } \\
\mathrm{R}=\text { key for structural equilibrium }\end{array}$ & 2 & 1 \\
\hline \multirow[t]{2}{*}{$\ldots}$. & $\ldots$ & $\ldots$ & $\ldots$ & $\ldots$ & $\ldots$ & $\ldots$ \\
\hline & & & & & total rating & $\mathrm{n}_{\mathrm{SRS}}$ \\
\hline
\end{tabular}

Fig. 3. Cut out of the categorization of performance indicators at different levels, taking into account different aspects

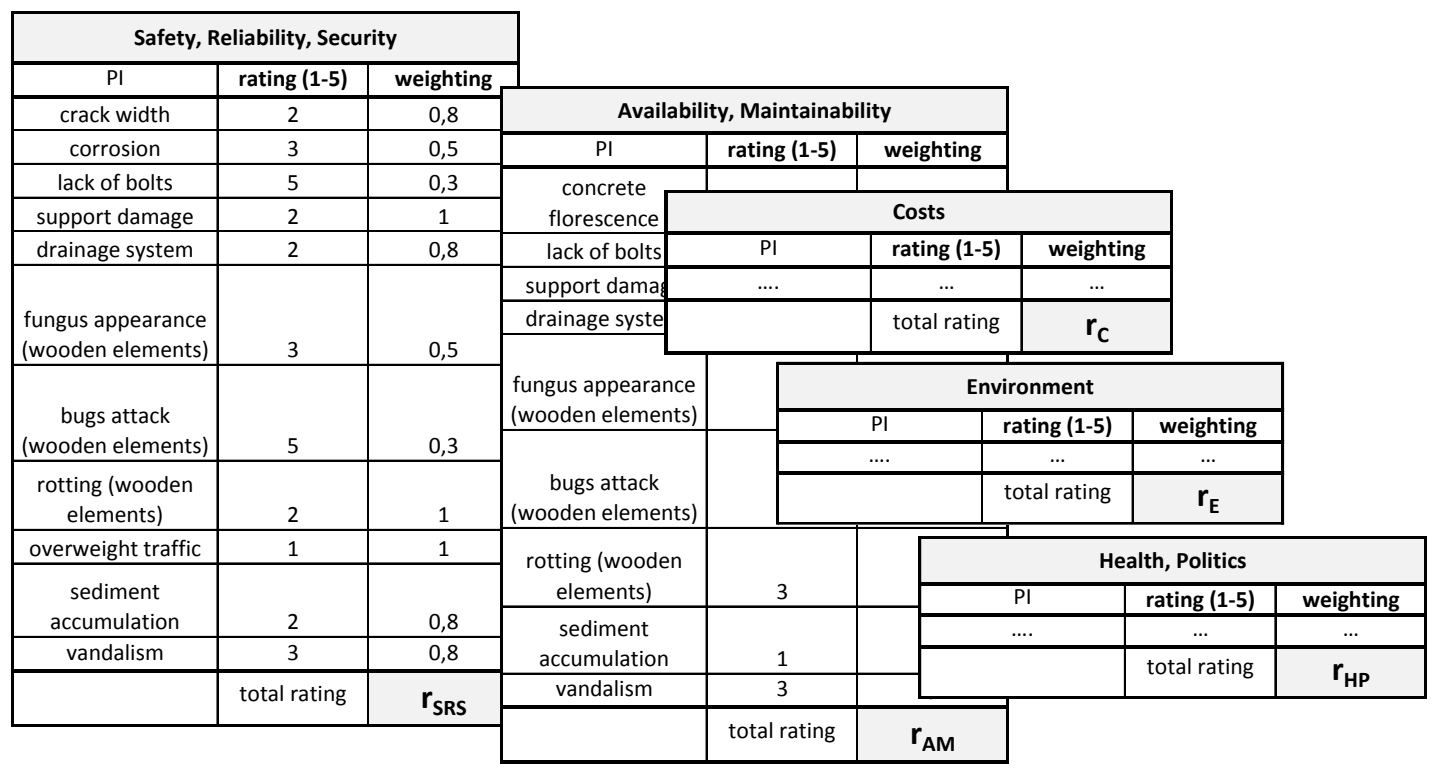

Fig. 4. Rating and weighting scheme related to five main groups of key performance indicators

Further process will require allocation of rating value (1-5, as in table 1) and weighting factor (whose values are stil to be defined) to each PIs related to five main groups of Key Performance indicators which are established in relation to requirements of the Working Groups 2 and 3 (Figure 4). The final rating and weighting will reveal overall rating (with rating factors $\mathrm{r}_{\mathrm{SRS}}, \mathrm{r}_{\mathrm{AM}}, \mathrm{r}_{\mathrm{C}}, \mathrm{r}_{\mathrm{E}}$ and $\mathrm{r}_{\mathrm{HP}}$ ) of each of the five most important KPIs groups. 
Example is presented with the Figure 5. Green areas represent the most favourable rate and the red areas should alarm the bridge operator and require immediate intervention.

\begin{tabular}{|c|c|}
\hline \multicolumn{2}{|c|}{ KPI } \\
\hline Safety, Reliability, Security & $\mathbf{r}_{\text {SRS }}$ \\
\hline Availability, Maintainability & $\mathbf{r}_{\mathrm{AM}}$ \\
\hline Costs & $\mathbf{r}_{\mathrm{C}}$ \\
\hline Environment & $\mathbf{r}_{\mathrm{E}}$ \\
\hline Health, Politics & $\mathbf{r}_{\mathrm{HP}}$ \\
\hline
\end{tabular}

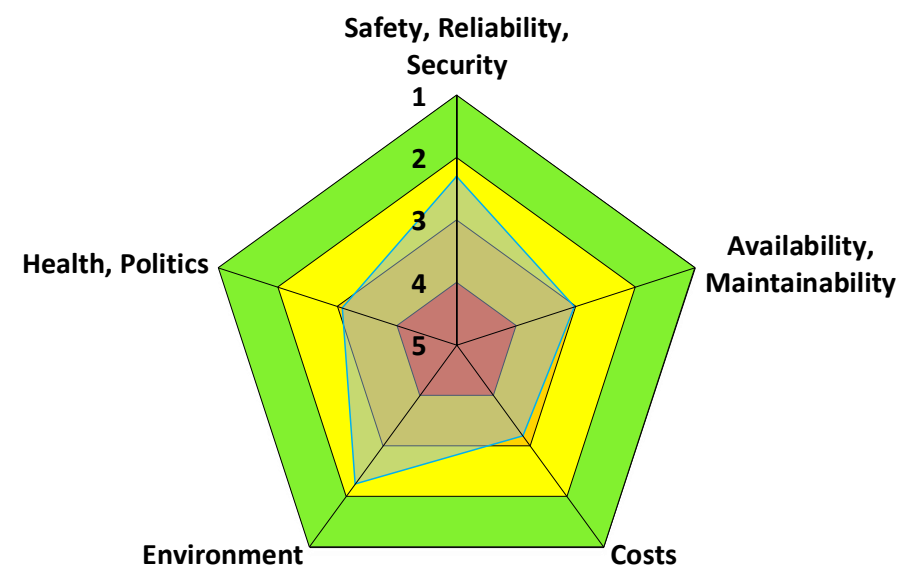

Fig. 5. Overall rating example of each of the five most important KPIs groups

\section{Conclusion}

The determination of performance indicators for bridge structures from European countries and its harmonization on a European level is complex, extensive, and time consuming process. After collecting the input from different countries, heterogeneous data on bridge performance aspects were systemized through clustering and homogenization of performance related terms. This is followed with the categorization of reduced list of actual PIs at different levels: component, system, network; taking into account different aspects: technical, sustainability and socio-economic. Categorization process is still undergoing, aiming final overall rating of each of the five most important groups of Key Performance Indicators required to define quality specifications and control plans of road bridges at the European level.

\section{Acknowledgements}

This paper is based upon work from COST Action TU-1406, Quality specifications for roadway bridges, standardization at a European level (BridgeSpec), supported by COST (European Cooperation in Science and Technology).

\section{References}

Matos J.C. 2016. An overview of COST Action TU1406, Quality Specifications for Roadway Bridges (BridgeSpec), Proceedings of the Fifth International Symposium on Life-Cycle Civil Engineering, Delft, The Netherlands (October 16-19, 2016).

Matos, J.C., Casas, J.R., Fernandes, S. 2016. COST Action TU1406 Quality Specifications for Roadway Bridges (BridgeSpec). Proceedings 8th international conference on Bridge Maintenance, Safety and Management, Foz do Iguaçu (Brazil), 26-30 June 2016. London: Taylor and Francis.

Strauss A. and Mandić Ivanković A. 2016. Performance Indicators for Roadway Bridges, Technical report of the Working group 1: Performance indicators of Cost Action TU1406

BundesministeriumfürVerkher, Innovation und Technologie, 2011. Quality Assurance for Structural Maintenance; Surveillance, Checking and Assessment of Bridges and Tunnels; Road Bridges, Vienna, Austria (in German)

County Surveyors Society CSS, 2004. Addendum to: CSS Guidance Note On Bridge Condition Indicators. Volume 2: Bridge Inspection Reporting, Lincoln, United Kingdom

Berichte der Bundesanstalt für Straßenwesen (BASt), 2015. Intelligente Brücke - Schädigungsrelevante Einwirkungen und Schädigungspotenziale von Brückenbauwerken aus Beton, Schünemann Verlag, Germany (in German) 